\title{
Prevailing motives for creating Ottoman heritage packaged tours in Macedonia
}

\author{
Biljana Petrevska (D) ${ }^{a}$, Ivanka Nestoroskab ${ }^{b}$ Petar Namicev ${ }^{c}$ and Svemir Gorin (D) ${ }^{d}$ \\ ${ }^{\mathrm{a} F a c u l t y ~ o f ~ T o u r i s m ~ a n d ~ B u s i n e s s ~ L o g i s t i c s, ~ G o c e ~ D e l c e v ~ U n i v e r s i t y, ~ S h t i p, ~ M a c e d o n i a ; ~}{ }^{\mathrm{b}}$ Faculty of Tourism and \\ Hospitality - Ohrid, St. Clement Ohridski University, Bitola, Macedonia; ' $A$ Academy of Art, Goce Delcev \\ University, Shtip, Macedonia; ${ }^{d}$ Institute of Geography, Faculty of Natural Sciences and Mathematics, Ss. Cyril \\ and Methodius University, Skopje, Macedonia
}

\begin{abstract}
This paper investigates the travel agencies' decision-making process in creating specific packaged tours. The main focus is the analysis of prevailing motives and the subsequent creation of tourist flows. Arranged packaged tours based on cultural heritage in Macedonia dating from the Ottoman period served as a testing ground for a flow analysis. We employed the demand-based Saint Gallen Destination Management (SGDM) model to reconstruct the visitor flows. The data were collected through interviews conducted with local tour guides who offer specifically tailored Ottoman heritage in Macedonia prearranged tours. The main study findings suggest that limited time for travel and sightseeing was the prevailing motive for the development of the current route flow, followed by price as an additional factor. By focusing on the fundamental factors, the main contribution of this paper is to obtain a better understanding of the current structure of the Ottoman heritage routes at both local and national level. From a practical perspective, based on the identified potential of the Ottoman heritage sites, the study recommends designing new routes, as well as urging more proactive attitude among tourism policymakers.
\end{abstract}

\section{ARTICLE HISTORY}

Received 4 March 2018

Accepted 9 July 2019

\section{KEYWORDS}

Motives; decision-making; Ottoman heritage route; SGDM model; demand-flow

\section{Highlight points}

- This article investigates the decision-making process of travel agencies in creating arranged packaged tours based on Ottoman cultural heritage in Macedonia.

- The study reconstructs tourist flows by applying the demand-based SGDM model and maps new routes associated with Ottoman heritage.

- It contributes to the diversification of supply and dispersion of visitor flows to regions that are not sufficiently promoted and developed.

- The research reveals that limited time for travel and sightseeing is the prevailing motive for the development of the current flow of the route, supplemented with the price as an additional factor. 
- The study enables better understanding of the nature of visitation patterns to sites related to cultural assets dating from the Ottoman period.

\section{Introduction}

Tourism development seeks to address questions related mostly to changes in travel behavior, sustainability and quality towards creating distinctive tourist products with the purpose of achieving better positioning in the tourist market. Cultural tourism, supported by heritage sites, is one of the leading features of the tourism industry resulting in the development of specific tourism products (Bond, Packer, \& Ballantyne, 2015; Dinis \& Krakover, 2016) and the creation of cultural heritage routes (Council of Europe, 2010; Graf \& Popesku, 2016; Majdoub, 2009). Heritage sites are often the leading, or supporting, spots on the tourism course, generally designed for specific groups of tourists and visitors (Moscardo \& Pearce, 1999). Heritage is a rising tourism product that provides tourists with experiences based on the (in)tangible remains of the past. This led to the inevitable relationship between the cultural heritage and tourism (Fonseca \& Ramos, 2012; Garrod \& Fyall, 2000; Loulanski \& Loulanski, 2011).

Furthermore, cultural tourism has the fastest pace of growth compared to other types of tourism, becoming mainstream for visitors who search for change (McKercher \& Chow, 2001) and wish to experience different cultures (Gilbert \& Terrata, 2001). This positive development stems from the new trends in the demographic, socio-economic sphere and current lifestyle (Korunovski, 2008).

The primary objective of this study was to analyse the arranged Ottoman heritage routes (OHR). The experiential approach was used as a tool for potential development of new OHR routes. This paper used the Saint Gallen Destination Management (SGDM) model (Beritelli \& Leasser, 2017; Beritelli, Reinhold, Laesser, \& Bieger, 2015) as a recently applied demand approach model to reconstruct visitor flows. Contrary to other studies, this paper concentrates on the particular motives that urge travel agencies, as driving policymakers, to create arranged tours for specific target groups. We applied the model to serve as a diagnostic tool to explore how travel agencies created Ottoman heritage sites (OHS) arranged tours and identify the integrated process through which decisions were made. Hence, the main research topic places direct emphasis on the content aspect of the attitude, as opposed to the structural aspect, by introducing new visitor flows. This may serve as guidance to marketers in the development of attitude change strategies.

Macedonia represents a suitable testing ground for investigation since it is rich with cultural heritage dating from the Ottoman period. The Ottoman heritage is of wide interest owing to its historical greatness being spread over a large geographical world area. Hence, the number of tourists who would choose such specifically tailored packaged tours could be reasonably expected to grow. Current routes, along with new OHR include cultural heritage that attracts visitors due to their connection to the specific heritage, history, background, or cultural experience.

Though many academics explore various topics related to the heritage dated from the Ottoman period, none has investigated the main factors that influence tourism market players in arranging such intense specific packaged tours, as this paper describes. Having in mind the perpetual interest in the Ottoman empire and its cultural heritage, this study 